\title{
Utilization of Squilla (Oratasquilla nepa) for Silage Production
}

\author{
K. Rathnakumar ${ }^{1,2 *}$ \\ ${ }^{1}$ Department of Fish Processing Technology, University of Agricultural Sciences, College of \\ Fisheries, Mangalore - 575 002, India \\ ${ }^{2}$ Department of Fish Process Engineering, College of Fisheries Engineering, Tamil Nadu \\ Fisheries University, Nagapattinam - 611 001, India \\ *Corresponding author
}

\section{A B S T R A C T}

\section{Keywords \\ Squilla, Acid silage, \\ Liquefaction, \\ Protein efficiency ratio}

\section{Article Info}

Accepted:

26 February 2018

Available Online:

10 March 2018
Squilla (Oratosquilla nepa) was minced and divided into 3 lots. Each lot was treated with 3 different acids such as formic acid, hydrochloric acid and sulphuric acid, the $\mathrm{pH}$ was brought down to 3.5, 2.5 and 2.5 of the respective lot. Liquefaction of tissue was more pronounced in the first few days. Chemical, biochemical, microbiological characteristics and liquefaction rate of acid treated squilla were studied upto 90 days. Protein efficiency ratio of squilla silage (Formic acid) based diet is 0.58 and skim milk powder is 2.34 .

\section{Introduction}

Fish silage is a stable liquid with a malty odour which has good storage characteristics. In India, squilla (Oratosquilla nepa) form a major component of shrimp by catch. Squilla landing during early eighties has been estimated at 24, 930 tons (CMFRI, 1984) and subsequently 65, 471 and 63,468 tons during 2000 and 2001 respectively (CMFRI, 2002). Disposal of squilla pose great difficulty as it produce obnoxious smell and create environmental problem. Attempts have been made to convert squilla into meal and prepare chitin, chitosan etc. In silage manufacture, once the acid is added to fish or inedible parts of fish, it neither attracts flies nor gives obnoxious odour, which inturn reduces most of the civic problems. Moreover, it requires less capital investment. Among mineral acids, sulphuric acid (SA) or a mixture of sulphuric acid and hydrochloric acids (HA) are used. The most commonly used organic acids are propionic, acetic and formic acids (FA) (Tatterson and Windsor 1974; Disney et al., 1978). As organic acids are expensive cheap mineral acids like SA or HA are used to lower the $\mathrm{pH}$ and organic acids like propionic or formic are added to it for antimicrobial activity (Gopakumar, 1997). The present study was undertaken to prepare acid ensilage utilizing FA, SA and HA. The process of 
liquefaction and the usefulness of squilla ensilage (FA) as a protein supplement in animal feed were studied.

\section{Materials and Methods}

\section{Preparation of silage}

Squilla (Oratosquilla nepa) was procured from fish landing centre at Mandapam and transported to lab in iced condition. Whole lot was washed, minced and divided into 3 batches. Each batch was treated with formic acid $(84 \mathrm{ml} / \mathrm{kg})$, hydrochloric acid $(78 \mathrm{ml} / \mathrm{kg})$ and sulphuric acid $(50 \mathrm{ml} / \mathrm{kg})$ respectively. Total volume of acid added at the end of $3^{\text {rd }}$ day for silage from formic acid (SF) to bring down the $\mathrm{pH}$ at 3.5 was $8.33 \%(\mathrm{~W} / \mathrm{W})$ or $6.67 \%(\mathrm{~V} / \mathrm{W})$, whereas it was $7.83 \%(\mathrm{~W} / \mathrm{W})$ or $6.67 \%(\mathrm{~V} / \mathrm{W})$ for silage from hydrochloric acid $(\mathrm{SH})$ and $6.61 \%(\mathrm{~W} / \mathrm{W})$ or $3.33 \%(\mathrm{~V} / \mathrm{W})$ for silage from sulphuric acid (SS) to get a $\mathrm{pH}$ of 2.5. Minced squilla was thoroughly mixed with acid, transfered to wide mouth glass containers and closed with screw caps.

\section{Analyses}

To study the liquefaction, a known quantity of sample was taken from well mixed silage and filtered in the bolting cloth for 15 minutes. The volume of filtrate and weight of residue were noted. Chemical composition such as moisture, protein, fat, ash (AOAC, 1980) and crude fibre content (Pearson, 1976) of raw material and final products were estimated.

The silages were analysed on $1^{\text {st }}, 3^{\text {rd }}, 7^{\text {th }}, 30^{\text {th }}$, $60^{\text {th }}$ and $90^{\text {th }}$ day. Everytime the silage were mixed well and samples were drawn. Biochemical characteristics like Total Volatile Base Nitrogen (TVB-N) (Beatty and Gibbons, 1937), Free Fatty Acid (FFA) (Olley and Lovern, 1960), Thiobarbituric Acid value (TBA) (Tarladgis et al., 1960). Non-Protein Nitrogen (NPN) (AOAC, 1975), Alpha-Amino
Nitrogen (AAN) (Pope and Stevens, 1939), Acid Value (AV) (AOAC 1975) and $\mathrm{pH}$ (Toshniwal combined electrodes) were estimated. Total Plate Count (TPC) and Mould Count (MC) were analysed according to the standard method recommended by APHA (1976). Protein efficiency ratio (PER) of dried powdered squilla silage prepared by using formic acid was estimated by AOAC (1975) method and skim milk powder served as control. Group of albino rats (21 days old) were fed for a period of 3 weeks PER was calculated using the formula

PER $=\frac{\text { Gain in body wt. }(g) \text { in } 3 \text { weeks }}{\operatorname{Protein} \text { in take }(g) \text { in } 3 \text { weeks }}$

Results obtained were analysed for significant difference using analysis of variance technique (Dixon and Massey, 1969).

\section{Results and Discussion}

Squilla has about $35 \%$ of flesh and the rest is shell material. Ash content was comparatively higher (Table 1) because of Calcium and Magnesium bound to chitinuous material of the shells (muzzarelli, 1977). Crude fibre mainly consists of chitin which is a polysaccharide that forms the skeletal portion of crustaceans. Madhavan and Ramachandran (1975) found chitin percentage in squilla was $14.7 \%$ on dry weight basis. They also observed that elevated dietary content of crude fibre obviously had a negative effect on the digestability of nutrients. However, absence of crude fibre must be regarded as unfavourable.

The quality of any of the final product depends on the raw material characteristics. Squilla used in the present study, was 18-20 hours old and not iced till it reaches the labouratory. Though squilla was not of prime quality, it was used because the squilla are available in this condition only. High level of $\mathrm{pH}$ and other biochemical parameter (Table 1) 
indicates considerable quantity of protein break down due to the bacterial and autolytic enzyme activity, a common post-mortem feature in fish and fishery products, which is similar to protease activity found in Antarctic Krill (Suzuki, 1981). Although the $\mathrm{pH}$ of the silage was mostly outside the range for maximum activity for enzymes, there was apparently sufficient activity to bring about reasonable liquefaction.

Marginal decrease in the moisture content (Table 2) may be due to some drying and evaporation occurred during the preparation and storage, which in turn caused slight increase in crude protein content. Total lipid, ash and crude fibre content were almost constant upto 90 days.

After the initial adjustment of $\mathrm{pH}$ of minced fish or minced crustaceans the $\mathrm{pH}$ increases during the storage of silage (Disney et al., 1978).

This is due to neutralisation effect by bones, shell material and buffering action of protein present in it. If $\mathrm{pH}$ increased beyond certain limit, silage may promote bacterial activity leading to spoilage, and to avoid that $\mathrm{pH}$ has to be brought down by adding acids. During the course of this study $\mathrm{pH}$ of silage prepared from formic acid and hydrochloric acid increased from 3.5 and 2.5 to 4.5 and 4.0 respectively on the $3^{\text {rd }}$ day, whereas $\mathrm{pH}$ of silage from sulphuric acid shows no change. After the readjustment of $\mathrm{pH}$ by adding respective acids, no change in $\mathrm{pH}$ was observed during storage.

In case of any silage volume of the material to be handled are very large and it should be possible to handle it using bulk liquid handling systems with pumps. The rate of liquefaction depends on the activity of digestive enzymes in the raw material, $\mathrm{pH}$, temperature and the preservative acids (Raa and Gildberg, 1982). Satisfactory liquefaction of silverbelly was found only to occur in silage containing viscera and heads (Jayawardena and Poulter, 1979). Raghunath and McCurdy (1990) found that addition of formic acid limited the increase in $\mathrm{pH}$ which in turn inhibit exopeptidase activity during autolysis causing no increment in amino nitrogen. Similar observation in 'acidstabilised' silage of pacific whiting was reported (Stone and Hard, 1986). In the present study, even though the rate of liquefaction was more upto $3^{\text {rd }}$ day in formic acid silage, maximum liquefaction took place in all the three silages within $7^{\text {th }}$ day and thereafter only marginal (Table 3 ). The degree of autolysis and protein solubilisation is 40$45 \%$ in tropical fishes like silver bellies (Gildberg and Raa, 1977). Resistance to proteolysis was attributed to presence of residue (Tatterson and Windsor, 1974, Hall et al., 1985a), disulphide cross-linking (Hall et al., 1985b) and accumulation of hydrophobic and aromatic amino acids in the residue. Nonpolar, ionic (electrostatic) and other association forces are also responsible for the insolubility of the sediment (Raghunath and McCurdy, 1987).

NPN of whole silverbelly silage increased from 14\% (of total nitrogen) to 39\% after 7 days (Jayawardena and Poulter, 1979). Steady increase in NPN indicates proteolysis of tissue proteins.

NPN content registered a rapid increase during first few days and slower thereafter (Fig. 1). Like in other fermented products NPN content is more in silage. This is mainly due to the action of proteases on protein which results in the formation of smaller molecular weight nitrogenous compounds (Durand, 1981).

Acid required for fish silage is $3.5 \%(\mathrm{~V} / \mathrm{W})$ in case of formic acid and $2.5 \%(\mathrm{~V} / \mathrm{W})$ in case of mineral acids (Muzzarelli, 1977). 
Table.1 Proximate, biochemical and microbiological characteristics of fresh squilla

\begin{tabular}{|l|c|}
\hline Moisture \% & 83.32 \\
\hline Protein $\%$ & 10.38 \\
\hline Total lipid \% & 0.65 \\
\hline Ash \% & 4.48 \\
\hline Crude fibre \% & 1.18 \\
\hline pH & 8.5 \\
\hline$\alpha$-amino nitrogen $(\mathrm{mg} / 100 \mathrm{~g})$ & 34.99 \\
\hline FFA $\%$ of total lipid as Oleic acid) & 35.82 \\
\hline TBA (mg of malonaldehyde/kg of material) & 0.15 \\
\hline TVB-n (mg/100 gm material) & 29.40 \\
\hline NPN $(\mathrm{mg} / 100$ gm) & 36.73 \\
\hline Acid value & 38.54 \\
\hline TPC & $5.7 \times 10^{6} / \mathrm{g}$ \\
\hline Mould count & $5.2 \times 10^{3 / g}$ \\
\hline
\end{tabular}

Table.3 Changes in rate of liquefaction during storage

\begin{tabular}{|c|c|c|c|}
\hline Storage period (days) & Rate of liquefaction* & SS \\
\hline & SF & SH & 10 \\
\hline 3 & 11 & 15 & 13 \\
\hline 7 & 25 & 20 & 15 \\
\hline 30 & 25 & 30 & 20 \\
\hline 60 & 30 & 32 & 22 \\
\hline 90 & 32 & 30 & 25 \\
\hline
\end{tabular}

*Volume of liquid collected (ml) from $100 \mathrm{~g}$ silage in 15 minutes after filtration.

Table.4 Ingredients used for the preparation of diets for animal feeding experiment

\begin{tabular}{|c|c|c|}
\hline Ingredients & S (\%) & M (\%) \\
\hline Milk powder & - & 10 \\
\hline Silage & 10 & - \\
\hline Oil & 10 & 10 \\
\hline Saltmiture & 4 & 4 \\
\hline Sugar & 10 & - \\
\hline Starch & 66 & 76 \\
\hline
\end{tabular}

S: Diets containing squilla silage M: Diets containing skim milk powder

Table.6 F-ratio values of various parameters of acid treated squilla during storage

\begin{tabular}{|c|c|c|c|c|c|c|}
\hline Source of variance & NPN & TVBN & AAN & FFA & TBA & AV \\
\hline Due to treatment & 2.64 & 15.59 & 0.0304 & 8.488 & 0.3608 & $34.35^{*}$ \\
\hline Due to period & $32.20^{*}$ & 9.12 & $562.92^{*}$ & $20.426^{*}$ & 0.0321 & 16.29 \\
\hline
\end{tabular}

Significant at 5\% level. 
Table.2 Changes in chemical composition during different period of storage

\begin{tabular}{|c|c|c|c|c|c|c|c|c|c|c|c|c|c|c|c|}
\hline Storage days & \multicolumn{3}{|c|}{ Moisture \% } & \multicolumn{3}{|c|}{ Crude Protein \% } & \multicolumn{3}{|c|}{ Total lipid \% } & \multicolumn{3}{|c|}{ Ash \% } & \multicolumn{3}{|c|}{ Crude fibre \% } \\
\hline & SF & $\mathrm{SH}$ & SS & SF & SH & SS & SF & SH & SS & SF & $\mathrm{SH}$ & SS & SF & $\mathrm{SH}$ & SS \\
\hline 0 & 76.51 & 76.45 & 74.20 & 10.07 & 10.19 & 11.92 & 0.85 & 0.79 & 0.76 & 5.23 & 6.34 & 6.65 & 2.12 & 2.23 & 2.97 \\
\hline 3 & 76.80 & 74.05 & 71.32 & 9.63 & 10.71 & 12.30 & 0.72 & 0.87 & 0.83 & 5.61 & 7.61 & 6.97 & 1.93 & 2.46 & 2.43 \\
\hline 7 & 77.42 & 77.24 & 70.37 & 9.53 & 9.85 & 11.50 & 0.86 & 0.82 & 0.83 & 6.19 & 7.36 & 6.19 & 2.01 & 2.45 & 2.68 \\
\hline 30 & 74.29 & 76.78 & 71.10 & 10.75 & 9.49 & 12.57 & 0.85 & 0.79 & 0.71 & 5.96 & 6.81 & 7.51 & 2.79 & 2.15 & 2.83 \\
\hline 60 & 75.64 & 77.95 & 72.32 & 11.06 & 10.22 & 11.95 & 0.83 & 0.82 & 0.77 & 5.8 & 6.78 & 6.67 & 2.10 & 2.52 & 2.81 \\
\hline 90 & 75.28 & 77.53 & 71.82 & 11.10 & 10.65 & 11.92 & 0.78 & 0.85 & 0.72 & 6.16 & 7.14 & 7.43 & 2.27 & 2.39 & 2.33 \\
\hline
\end{tabular}

* Values are the mean of three estimates.

Table.5 Protein efficiency ratio of squilla silage

\begin{tabular}{|c|c|c|c|c|c|c|c|c|c|}
\hline $\begin{array}{l}\text { Sl. } \\
\text { No. }\end{array}$ & $\begin{array}{l}\text { Source of } \\
\text { protein }\end{array}$ & $\begin{array}{l}\text { Level of } \\
\text { protein in the } \\
\text { diet }(\%)\end{array}$ & $\begin{array}{c}\text { initial weight } \\
\text { of rat }(\mathrm{g})\end{array}$ & $\begin{array}{c}\text { wt. of rat } \\
\text { after } 3 \text { weeks } \\
\text { (g) }\end{array}$ & $\begin{array}{c}\text { Gain/loss in } \\
\text { wt. after } 3 \\
\text { weeks (g) }\end{array}$ & $\begin{array}{c}\text { Diet intake at } \\
\text { the end of } 3 \\
\text { weeks }(\mathrm{g})\end{array}$ & $\begin{array}{l}\text { Protein } \\
\text { intake }\end{array}$ & PER & $\begin{array}{c}\text { Average } \\
\text { PER }\end{array}$ \\
\hline 1 & & & 22 & 49 & 27 & 117.5 & 11.24 & 2.40 & \\
\hline 2 & & & 22 & 38 & 16 & 85.5 & 8.18 & 1.96 & \\
\hline 3 & & & 31 & 55 & 24 & 117.0 & 11.19 & 2.14 & \\
\hline 4 & Skim milk & 9.57 & 22 & 50 & 28 & 132.0 & 12.63 & 2.21 & 2.34 \\
\hline 5 & Powder & & 35 & 77 & 42 & 172.0 & 16.51 & 2.54 & \\
\hline 6 & & & 40 & 82 & 42 & 183.5 & 17.56 & 2.39 & \\
\hline 7 & & & 42 & 91 & 49 & 189.0 & 18.08 & 2.71 & \\
\hline 8 & & & 25 & 55 & 30 & 134.0 & 12.82 & 2.33 & \\
\hline 1 & & & 38 & 45 & 7 & 118.0 & 12.84 & 0.54 & \\
\hline 2 & & & 31 & 36 & 5 & 123.5 & 13.44 & 0.37 & \\
\hline 3 & & & 45 & 41 & -4 & 118.0 & 12.84 & 0.31 & \\
\hline 4 & Squilla Silage & 10.88 & 41 & 53 & 12 & 130.0 & 14.14 & 0.85 & 0.58 \\
\hline 5 & & & 20 & 25 & 5 & 90.0 & 9.79 & 0.51 & \\
\hline 6 & & & 23 & 30 & 7 & 100.5 & 10.93 & 0.64 & \\
\hline 7 & & & 34 & 42 & 8 & 114.5 & 12.46 & 0.64 & \\
\hline 8 & & & 24 & 30 & 6 & 108.0 & 11.75 & 0.51 & \\
\hline
\end{tabular}




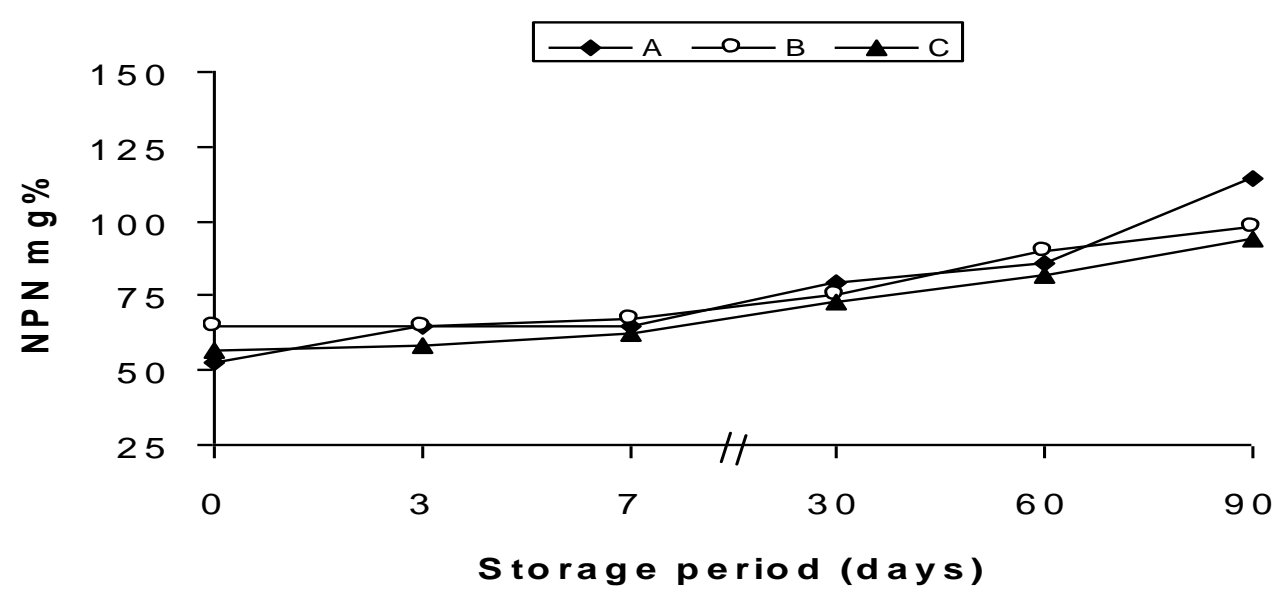

$$
\rightarrow A \rightarrow C \rightarrow C
$$
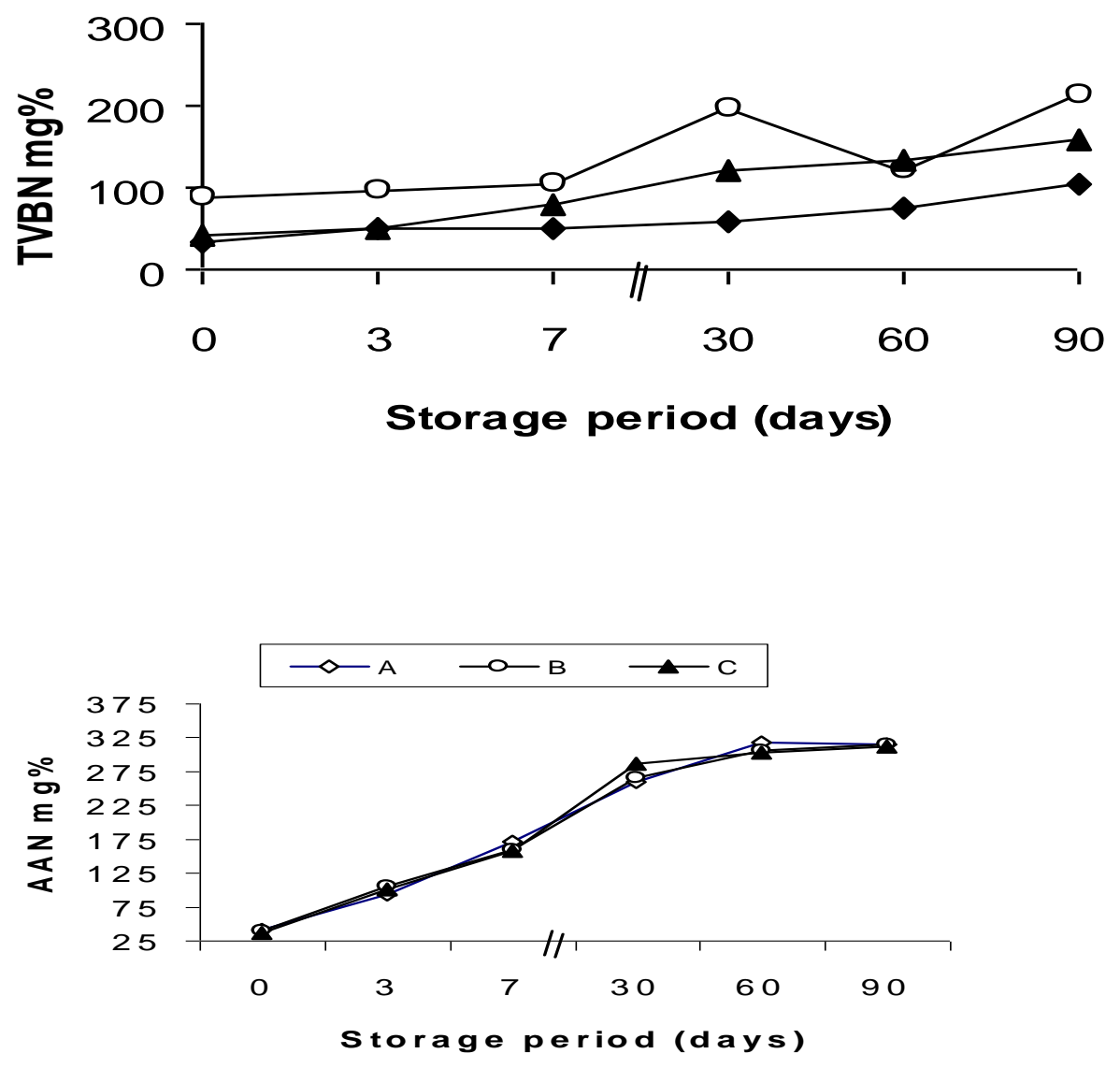


$$
\multimap A \multimap B \multimap C
$$

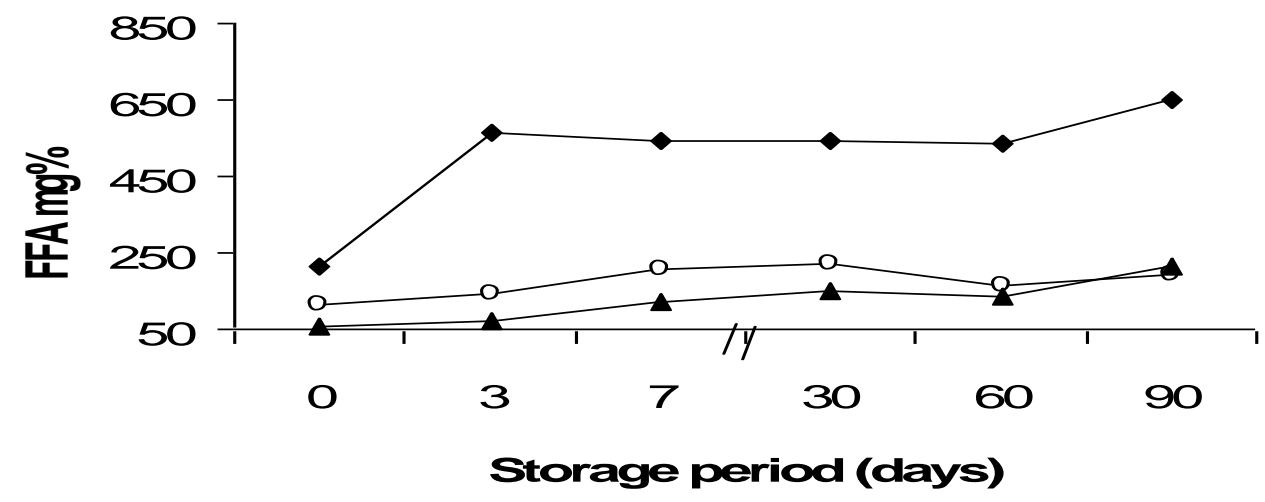

$$
\rightarrow A \rightarrow B \rightarrow C
$$

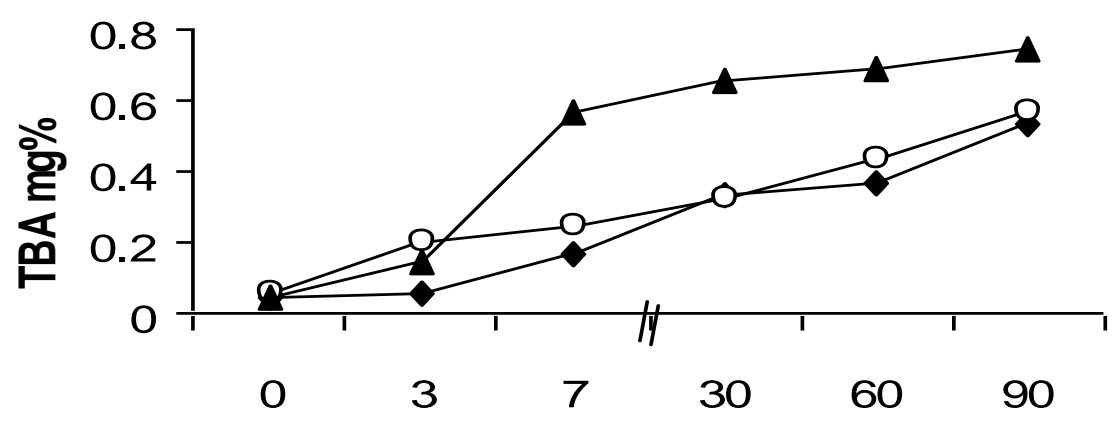

Storage period (days)

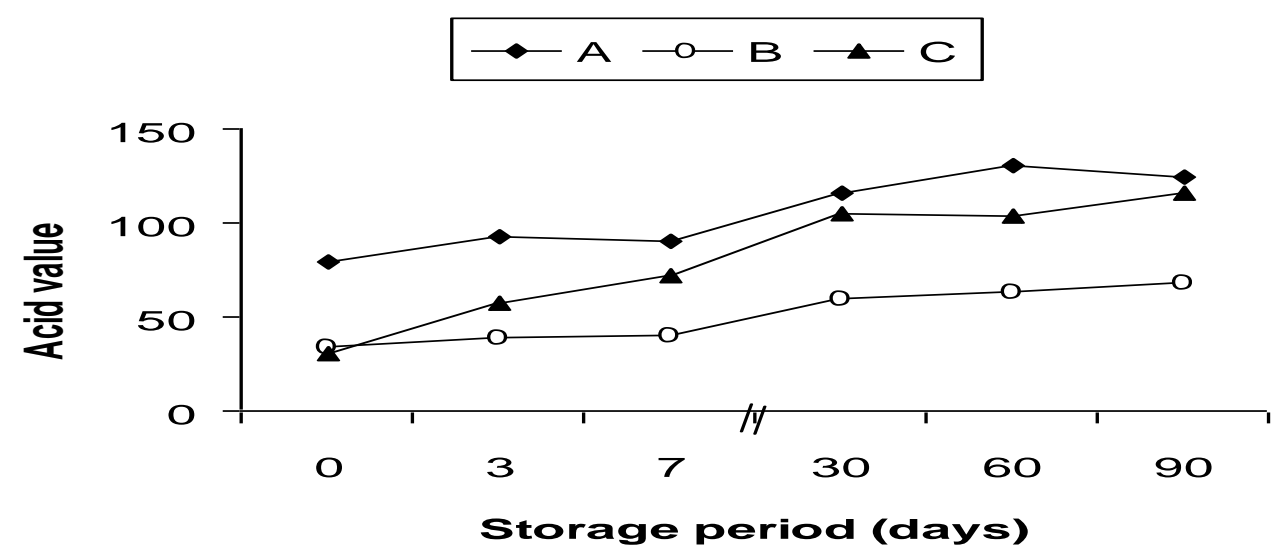


Ariyani and Buckle (1991) used a mixture of $8 \%(\mathrm{~V} / \mathrm{W})$ formic acid and propionic acid (1:1 $\mathrm{V} / \mathrm{W})$ to produce stable prawn head silage. Calcium and magnesium ions are found to occur along with chitin in the exoskeletons of crustaceans (Muzzarelli, 1977), when acids were added to chitinous materials, respective salts of calcium and magnesium are formed. Higher requirements of acid for crustaceans (squilla) than fish to bring down the $\mathrm{pH}$ to the required level are attributed to the above reasons.

Increase in TVBN is more in silage prepared by hydrochloric acid (Fig. 2) than other two. Since TPC in all silages was nil, the increase in TVBN is mainly due to hydrolysis of protein and may be due to deamination of amino acids with production of Ammonia. Increase in TVBN with length of storage is mainly attributed to the production of $\mathrm{NH}_{3}$ (Adebona, 1978). Haaland and Njaa (1989) used TVN and $\mathrm{NH}_{3}$ as index of quality for fish silage and also observed that in properly preserved silage TVBN and $\mathrm{NH}_{3}-\mathrm{N}$ increase during storage. Raa and Gildberg (1982) also observed similar increase in TVBN in cod viscera silage.

Alpha amino nitrogen (AAN) is an index of free amino groups and also a measure of proteolysis. AAN showed a steady increase (Fig. 3) in all three silages. Ariyani and Buckle (1991) observed similar increase in amino groups in prawn head silage during storage. FFA content was high in formic acid silage compared to other two (Fig. 4). Tatterson and Windsor (1974) found that FFA content in silage prepared from fatty fishes reached $20 \%$ of the lipid content after one year at $23^{\circ} \mathrm{C}$. Reece (1980) has attributed the increase in FFA content of sprat silage due to the action of lipases in the presence of organic acids and to release of FFA at aid $\mathrm{pH}$ from water - miscible salts. The action of lipases in the presence of formic acid may be the reason for higher FFA production in formic acid silage. However, hydrolysis of fats in the presence of acid cannot be ruled out. Added organic acid may come into hot neutral alcohol fraction during FFA estimation and probably that may be the reason for high FFA content in organic acid silages.

The major reactant in the TBA determination is malonaldehyde. The chief source of malonaldehyde is the oxidation of PUFA (Dahle et al., 1962). TBA registered a slow increase during storage (Fig. 5). This indicates that, either the fatty acids have oxidised slowly or instead of accumulating as aldehyde, they may be removed by combining with other protein break down products (Gould and Peters, 1971). Hall and Ledward (1986) find a decline in TBA value in normal silage, while the defatted silage had lower initial value, which increased on storage.

Acid value includes the liberated FFA and added acid which in turn provides a measure of the extent of hydrolytic rancidity during storage. Formation of peroxides and their break down to less carbon atom fatty acids eventually increase the acid value of fish meal (Leroy, 1960). High acid value at zero day and sudden increase on $3^{\text {rd }}$ day was due to added acid and liberated FFA (Fig. 6). High FFA is probably reason for high acid value of formic acid silage.

Total plate count was found to be $5.2 \times 10^{4}$, $3.5 \times 10^{4}$ and $3.2 \times 10^{4}$ per gram for SF, SH and SS samples respectively on zero day. No microbial growth was observed from $3^{\text {rd }}$ day till the end of study period. Mould count of $2.8 \times 10^{2}, 3.5 \times 10^{2}$ per gram for SF and SS were observed on zero day and subsequently absent during entire study period. Whereas mould count was absent in SH from zero day on verse. Most of bacteria die at $\mathrm{pH}$ less than 3.5 and some acid resistant bacteria may survive. TPC observed in the present study is 
much lower than the observation made by James et al., (1976). Most moulds can grow over a wide range of $\mathrm{pH}(2-8.5)$ but the majority is favoured by an acid pH (Frazier, 1958). No mould growth may be attributed that, the type of mould, which grows at $\mathrm{pH}$ less than 3.5 , is absent.

All the rats fed with skin milk powder diet were healthy and showed increase in growth (Table 4 and 5) whereas the rate fed on diets from squilla has become weak after few days. Decrease in weight and leg weakening was observed, but no mortality occurred. Such symptoms and poor growth have been reported (Disney et al., 1978; Gildberg and Raa, 1977). PER of 3.2 with skim milk powder and PER of 3.3 in silage diet from fresh water fish with rats was reported (Krishnaswamy et al., 1965). Poor growth rate cannot be due to residual organic acid because the chicks grow fast on conventional broiler diet with $1 \%$ formic acid or $1 \%$ formic/ propionic acid (Disney and Hoffman, 1976; Kompiang et al., 1979). Nutritional value was very poor in silage prepared from spoiled fish (Raa and Gildberg, 1982). Incorporating poor quality silage in feed cause leg weakness and perosis/ slipped tendon symptoms in the birds (Disney et al., 1978). Satisfactory results were obtained using diet containing 5\% (Pong pen et al., 1979) and 20\% silage (Poulter et al., 1979) on chicken. Feeding trials conducted on pigs confirm that silage could serve as an active protein supplement without causing any ill effects (Disney et al., 1978; Rangkuti et al., 1979). Chitin may effect digestability and growth. Diet containing chitin $(0.5 \%)$ cause weight reduction in albino rats (Mathew et al., 1989), whereas weight gain in broiler chicks (Nair et al., 1993) were observed.

Poor performance of silage diets may be presence of high concentration of residual acids, spoilage of raw materials, vitamin deficiencies (B, C \& E), loss of aminoacids as well as micronutrients (manganese) and presence of oxidised lipids (Raa and Gildberg, 1982).

It is evident from the table 6 that acids used did not show any significant $(\mathrm{p}>0.05)$ influence on the parameters studied except acid value. Whereas, NPN, AAN and FFA content vary significantly $(\mathrm{p}<0.05)$ during storage period.

Though silages possessed many advantages over meal as a protein supplement, the feeding experiment with albino rat to determine PER did not give encouraging results due to the animal avoiding feed containing silages and there by losing weight. Though physical and chemical characteristics of silage are acceptable a detailed study to look into factors such as quality of the acids used, effect of drying of silage on the quality, presence of chitin, and heavy metal impurities during storage is required.

\section{References}

Adebona, M.B. 1978. Changes in total volatile base during salt preservation of Sardinella eba and Clupea harengus. In: IPFC Proceedings, Manila, Philippines. (8-11 March 1978). 370374.

AOAC, 1975. Official methods of analysis, $12^{\text {th }}$ ed. Association of Official Analytical Chemists, Washington, DC.

AOAC, 1980. Official methods of analysis, $13^{\text {th }}$ ed. Association of Official Analytical Chemists, Washington, DC.

APHA (American Public Health Association), 1976. Compendium of methods for the microbiological examination of foods. M.L. Speck (Ed.), APHA, New York.

Ariyani, F., and Buckle, A. 1991. Ensiling of prawn heads. Asean Food J. 6(2): 5863. 
Beatty, S.A., and Gibbons, N.E. 1937. The measurement of spoilage in fish. $J$. Biol.Bd. Can. 3(1): 77-91.

CMFRI, 1984. Annual Report. Central Marine Fisheries Research Institute, Cochin, India.

CMFRI, 1991. Annual Report. Central Marine Fisheries Research Institute, Cochin, India.

CMFRI, 1992. Annual Report. Central Marine Fisheries Research Institute, Cochin, India.

Dahle, L.K., Hill, E.G., and Holman, R.T. 1962. The Thiobarbituric acid reaction and the autoxidation of polyunsaturated fatty acids methyl esters. Arch. of Biochem. and Biophys. 98: 253-261.

Deepak, G. 1993. Utilisation of squilla and prawn shell waste for silage production. (M.F.Sc. Thesis) Univ. Agri. Sci., Bangalore.

Disney, J.G., and Hoffman, A. 1976. A dried fish silage product. In: Proc. Torry Res. Stn. Symp. Fish silage. Torry Research Station Aberdeen.

Disney, J.G., Hoffman, A., Olley, J., Chiveri, I.J., Barranco, A., and Francis, B.J. 1978. Development of a fish silage/carbohydrate animal feed for use in the tropics. Tropical Science. 20(2): 129-144.

Dixon, J.W., and Massey, Jr. J.F. 1969. Introduction to statistical analysis. McGraw-Hill, Inc., New York.

Durand, P. 1981. Study of the nitrogenous soluble part of the anchovy after barral salting during ripening. Rev. Trav. Inst. Peaches. Marit., Nantes 45(4): 271-281.

Frazier, W.C. 1958. Food Microbiology. McGraw-Hill Book Company Inc., New York.

Gildberg, A., and Raa, J. 1977. Properties of a propionic acid/formic acid preserved silage of cod viscera. J. Sci. Food Agric. 28: 647-653.
Gopakumar, K. 1997. Tropical Fishery products, Oxford and IBH publishing Co. Pvt. Ltd. NewDelhi.

Gould, E., and Peters, J.A. 1971. On testing the freshness of frozen fish. Fishing New (Books) Ltd. London.

Haaland, H. and Njaa, L.R. 1989. Total volatile nitrogen-a quality criterion for fish silage. Aquaculture., 79(1-4): 311316.

Hall, G.M., and Ledward, D.A. 1986. Silage from tropical fish. 3. Lipid behaviour. J. Food Technol. 21(1): 45-54.

Hall, G.M., Keeble, D. Ledward, D.A., and Lawrie, R.A. 1985a. Silage from tropical fish proteolysis. J. Food Technol. 20: 561.

Hall, G.M., Ledward, D.A., and Lawrie, R.A. 1985b. Silage from tropical fish 2 . Undigested fraction. J. Food Technol. 20: 573.

James, M.A., Iyer, K.M., and Nair, M.R. 1976. Comparative study of fish ensilage prepared by microbial fermentation and formic acid ensilage. In: Proceedings of the conference on the handling, processing and marketing of tropical fish. Tropical Products Institute, UK. 273-276.

Jayawardena, K.M., and Poulter, R.G. 1979. Studies on the preparation of fish silage II. Rate of liquefaction of different tissues of silverbelly. In: Proc. IPFC Workshop Fish Silage, FAO Fish Rep. No.230: 35 .

Kompiang, I.P., Yushadi and Creswell, C.D. 1979. Microbial fish silage Chemical composition, fermentation characteristics and nutritional value. In: Proc. IPFC Workshop Fish Silage. FAO Fish Rep. No.230:38.

Krishnaswamy, M.A., Kodkol, S.B., and Revankar, G.D. 1965. Nutritional evaluation of an ensiled product from fish. Can. J. Biochem. 43: 119-177. 
Leroy, A.M. 1960. Problems souleres par 1' utilisation des farine de poisson pour 1 'alimentation des animaux. In: E. Heen and R. Kreuzer (Eds.) pp. 312-319. Fishing News Books Ltd., London.

Madhavan, P., and Ramachandran, N.K.G. 1975. Chitosan from squilla. Fish. Technol. 12(1): 81.

Mathew, P.T., Ramachandran Nair, K.G., Madhavan, P., and Prabhu, P.V. 1989. Effect of chitin and prawn shell on the growth of albino rat. Fish. Technol., 26(1): 36-38.

Muzzarelli, R.A.A. 1977. Chitin. Pergamon Press, p. 24.

Nair, R.K.G., Mathew, P.T., Madhavan, P., and Prabhu, P.V. 1993. Effect of feeding chitin on poultry. Fish Technol., 30(1): 24-27.

Olley, J., and Lovern, J.A. 1960. Phospholipid hydrolysis of cod flesh stored at various temperatures. J. Sci. Fd. Agric. 11(1): 644-652.

Pearson, D. 1976. The chemical Analysis of Food. Churchill, London.

Pong pen, R., Wongehinda, N., and Swaehathamwongraton, S.I. 1979. Studies on nutritine value of fish silage for chicken II. Fish silage in Thailand further trails on broiler chicken. FAO Fish Rep. 230: 48.

Pope, C.G., and Stevens, M.F. 1939. The determination of amino nitrogen using a copper method. Biochem. J. 33: 10701077.

Poulter, R.G., Jayawardena, K.M., Ganegoda, P. and Ranaweera, K.N.P. 1979. Studies on fish silage in Srilanka, Summary. FAO Fish Rep. 230: 64.

Raa, J., and Gildberg, A. 1982. Fish silage - A review. CRC Crit. Rev. Food Sci. Nutr. 18(4): 383-420.

Raghunath, M.R., and McCurdy, A.R. 1987. Autolysis instant sediment in fish silage. Bio. wastes, 20: 227.

Raghunath, M.R., and McCurdy, A.R. 1990. Influence of $\mathrm{pH}$ on the proteinase complement and proteolytic products in rainbow trout viscera silage. J. Agric. Food Chem. 38: 45-50.

Rangkuti, M. Batubava, I. and Agus, M. 1979. Fish silage for pig production. In IPFC workshop on fish silage. FAO Fish. Rep. 230.

Reece, P. 1980. Control and reduction of free fatty acid concentration in oil recovered from fish silage prepared from sprat. J. Sci. Fd. Agric. 31: 147-155.

Stone, F.S., and Hard, R.W. 1986. Nutrional value of acid stabilized silage and liquefied fish protein. J. Sci. Food Agric. 37: 797.

Suzuki, T. 1981. Fish and krill protein: Processing Technology, Applied Sci. Publ., London.

Tarladgis, B.G., Watts, B.M., Younathan, M.T., and Dugan, L. 1960. A distillation method for the quantitative determination of malonaldehyde in rancid foods. J. Amer. Oilchem. Soc. 37: 44-48.

Tatterson, I.N., and Windsor, M.L. 1974. Fish silage. Torry Advis. Notes. 64: 6.

\section{How to cite this article:}

Rathnakumar, K. 2018. Utilization of Squilla (Oratasquilla nepa) for Silage Production. Int.J.Curr.Microbiol.App.Sci. 7(03): 3102-3112. doi: https://doi.org/10.20546/ijcmas.2018.703.360 